Vol. 4, No. 1, 2021

\author{
A. S. Masyuk, D. S. Katruk, V. Ye. Levytskyi \\ Lviv Polytechnic National University, \\ Department of Chemical Technology of Plastics Processing

\section{MODIFIED POLYVINYL CHLORIDE COMPOSITES WITH METAL-CONTAINING POLYMER-SILICATE FILLERS}

https://doi.org/10.23939/ctas2021.01.186

The influence of the nature of the metal-containing polymer-silicate fillers on morphology, surface hardness, Vicat softening point and elastic-plastic properties of PVC plasticates has been researched. The influence of polymer-silicate fillers on physic-mechanical and thermal properties and the conditions directional regulation of technological and operational properties of modified composites has been established.

Key words: poly(vinyl chloride); modification; polymer-silicate filler; composite.

\section{Introduction}

Development of new poly(vinyl chloride) (PVC) materials, including composites, given increased attention due to their wide use for various purposes in sheets, pipes, hoses, profiles, coatings products for constructional purposes, etc. In addition, the polyester materials are widely used as paints, sealants, fillers, as coherent for manufacturing products for various purposes [1]. Due to physical modification of PVC applications due to the introduction annexes of various nature, can creates materials with the required set of performance indicators for product specific practical purpose. Polymer composite materials, including plasticized PVC and modified consist of continuous polymer matrix, which is uniformly distributed discrete or continuous phase filler [2]. Thus, the role of the polymer matrix is to create a strong link between the individual elements and providing filler composite monolithic and capacity for processing in a highly elastic and viscous-flow state [3, 4]. The filler gives the composite strength, toughness, heat resistance and other valuable properties [5]. In addition, the surface of the filler affects the processes of structure formation in the surface layer and in composites under certain conditions implemented such properties that had none of the components alone [6].

Polymer composite materials, which, along with the basic polymer containing high molecular modifier, marked unlimited opportunities to influence the nature and content as polymer modifier, and filler morphology material $[1,2]$, and thus the complex technological and operational properties.

The properties of polymer composites largely depend on the nature of the polymer matrix and filler. The modified silicate fillers significantly improve physical-mechanical, and thermal properties of polyamide 6 [7] and polypropylene [8] and metalcontaining - increase the thermal stability and fire resistance of thermoplastics, including poly(vinyl chloride) [9], due to the mutual influence of the components on the morphology of the composites. Directed introduction of polymer modifiers, fine fillers allows you to adjust physico-mechanical, thermal, physico-chemical properties of the modified materials widely.

Previous dissolving polystyrene modifier in diesterphtalate plasticizer and then combining the resulting solution or suspension of fine PVC allows to obtain a modified PVC materials marked manufacturability during processing as rolling and extrusion and uniform distribution of components. Such modified materials depending on the nature of the plasticizer and polymer modifier observed different set of physical-mechanical and thermal properties.

At the same time, increasing technological and operational properties of polymer composite materials, including PVC, is achieved only when the interaction between the components of the composite are stored during its operation. This is only possible when their interactions at the interfaces, which 


\section{Modified polyvinyl chloride composites with metal-containing polymer-silicate fillers}

improves compatibility filler and polymer matrix. Among the methods to increase interoperability between components of polymer composites are widely used methods related to the previous modification fillers inorganic nature the functionsactive macromolecular compounds adsorption of the inorganic fine particles or as a result of joint fillers and deposition of the fine functions-active macromolecular compounds [10]. Compatible the functions-active deposition of water-soluble macromolecular compounds and silicates, compared to other methods of modification allows obtaining polymer-silicate materials in which the modifier is uniformly distributed in the silicate framework

The aim of this study is to establish the influence of polymer-silicate filler to features of obtaining PVC composites.

\section{Materials and methods of research}

The test samples were prepared from PVC brand Lacovyl PB1156. Plasticizers performed purified dioctylphtalate (DOP). As the polymer modifier was used suspensive polystyrene (PS) and shockresistant polystyrene. As fillers used metalcontaining polymer-silicate filler (PSF), in which the macromolecules uniformly distributed silicate framework. The polymer-silicate composites prepared by the developed technology $[10,11]$ compatible with deposition solution of sodium silicate and surfactant polymers (polyvinylpyrrolidone (PVP) and polyvinyl alcohol (PVA)) under the action of hydrochloric acid chlorides or metals of different nature. Fillers have a developed highly active surface [12].

Polystyrene modifier previously dissolved in the plasticizer, followed by the combination of PVC and polymer-inorganic filler. Then composition was gelatinized for 1 hour at $363 \mathrm{~K}$, followed by rolling at $418 \mathrm{~K}$ or extrusion in the extruder type Cellier. To prepare composites of fine polymer-silicate composite pre-mixed with PVC in the mixer MShL-1.

SEM studies were performed applying a REMMA 102-02 scanning electron microscope. The sample surface was scanned using an electron beam with a diameter of several nanometers and an electron energy of $0.2-40 \mathrm{kV}$. Zoom change range 10-30000, the resolution is about $5 \mathrm{~nm}$. Research was conducted on material with a conductive coating.

Vicat softening point of the investigated materials was determined in accordance with ISO 306: 2013B, the loading was $50 \mathrm{~N}$.
The surface hardness of the conical fluidity point was determined applying Hepler Consistometer at $293 \mathrm{~K}$ by indentation of the steel zone in the polymer sample with a sharpening angle of $58^{\circ} 08^{\prime}$ under a load of $50 \mathrm{~N}$ for $60 \mathrm{~s}$.

Thermomechanical studies were performed on a Hepler consistometer in accordance with ISO 11359-1:1999. According to the method, the values of deformation of the sample in the form of a tablet with a thickness of $5 \mathrm{~mm}$ with a change in temperature under the action of a rod with an area of $23.7 \mathrm{~mm}^{2}$ load of $5.0 \mathrm{~kg}$ were determined. The initial temperature of the studies was $293 \mathrm{~K}$. The depth of indentation of the rod in the sample was removed every $0.5 \mathrm{~K}$.

The study of elastic-plastic properties was performed on 5 samples, which were plates with a smooth surface with a width of not less than $15 \mathrm{~mm}$ and a thickness of not less than $5 \mathrm{~mm}$, on the device TSHR-76 according to ISO 7619.

\section{Research results and their discussion}

The performance properties of composite materials based on thermoplastic polymers, in particular polyvinyl chloride, differ significantly from unfilled thermoplastics. For polymeric composite materials, these properties can be widely adjusted by the physical state and nature of the source components, the nature of the distribution of ingredients in the volume of the material, thermal edging, processing parameters, and so on [13, 14].

In this regard, studies of the basic physical, mechanical and thermophysical properties of materials based on modified PVC plastics and polymer-inorganic fillers are of considerable interest.

Using scanning electron microscopy were investigated morphological characteristics of PVC plastic depending on the nature of the polymer modifier and polymer-silicate filler. The results obtained are shown in Fig. 1.

It should be noted that the modified by polystyrene PVC plastic marked uniform distribution of the polymer modifier in the volume of polymer matrix. In addition, the fine particles of PS are marked uniform swelling in the plasticizer, which apparently is a consequence of polystyrene macromolecules that are in solution in the plasticizer. Methods used the introduction of polymer-silicate composite allowed to distribute the modified filler in the polymer matrix. 


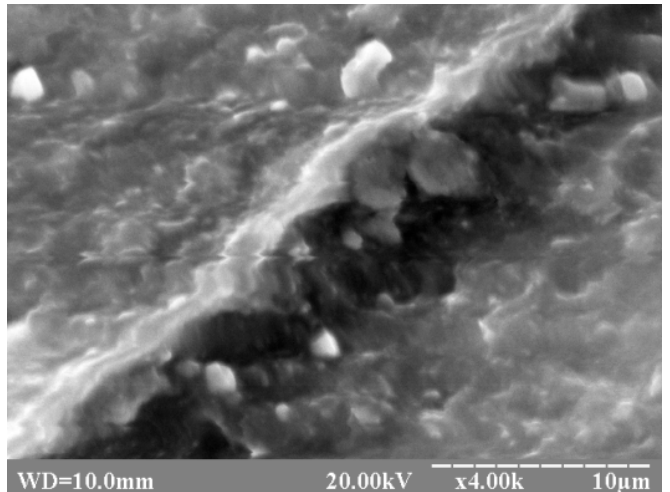

$a$

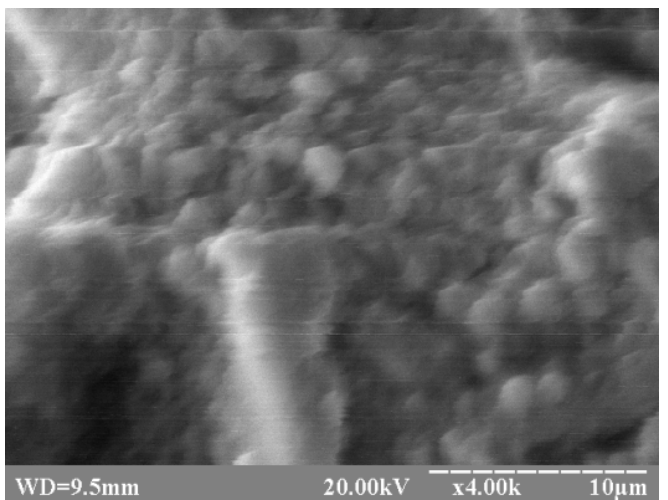

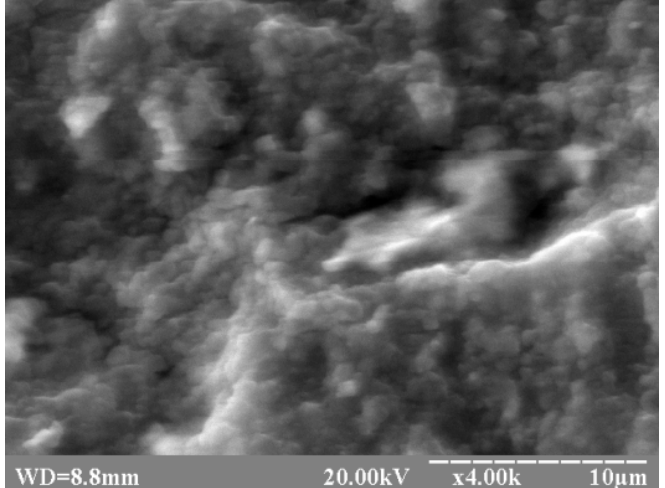

$b$

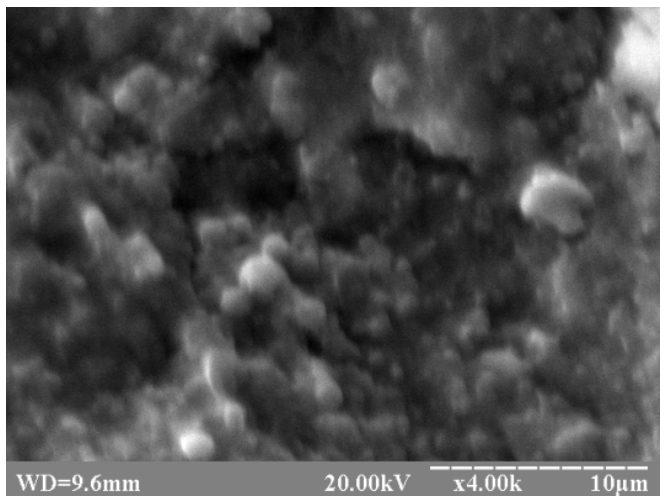

$d$

Fig. 1. SEM photography of chips modified PVC material (PVC : DOP = 100:30).

Modifier (2,8 parts by weight): $a$-without modifier; $b, c$-suspensive polystyrene;

$d$-shockproof polystyrene. Filler (1 parts by weight): $a, b$-without filler; $c, d-Z n, B a-$ silicate composite

Revealed changes in the morphology of materials significantly affect the physico-mechanical and thermal properties of PVC plastic.

As modified and non-modified polymer-silicate composite increases Vicat softening point $\left(T_{V}\right)$ and surface hardness of PVC composites (F) (Table 1).

Table 1

\section{Influence of $\mathrm{Cu}$ - containing polymer-silica filler on physico- mechanical and thermal properties of modified PVC plastic} (PVC: PS: DOP = 100: 2.8: 30 parts by weight)

\begin{tabular}{|c|c|c|c|c|c|c|}
\hline \multirow[b]{2}{*}{ No. } & \multicolumn{3}{|c|}{ Modifier of PSF, $\% \mathrm{wt}$} & \multirow[b]{2}{*}{$S, \%$} & \multirow{2}{*}{$\begin{array}{c}F, \\
\mathrm{MPa}\end{array}$} & \multirow[b]{2}{*}{$T_{V}, \mathrm{~K}$} \\
\hline & $\begin{array}{l}\text { Without } \\
\text { modifier }\end{array}$ & PVP & PVA & & & \\
\hline 1 & - & - & - & 59.0 & 80.7 & 311 \\
\hline 2 & 1 & - & - & 45.2 & 85.8 & 335 \\
\hline 3 & 10 & - & - & 55.0 & 96.0 & 334 \\
\hline 4 & - & 1 & - & 55.1 & 68.5 & 328 \\
\hline 5 & - & 10 & - & 46.9 & 76.4 & 340 \\
\hline 6 & - & - & 1 & 43.5 & 61.2 & 340 \\
\hline 7 & - & - & 10 & 36.7 & 80.2 & 344 \\
\hline
\end{tabular}

Modified polymer-silicate composite by polyvinylpyrrolidone increasingly affects the physicomechanical and thermal properties of PVC composites. This may be due to the completion of the process of structure formation, dense packing of macromolecules and filling the pores under the influence of macromolecules polyvinylpyrrolidone in their content of $2-5 \%$ in silicate fillers.

Introduction 5-10 \% polymer-silicate composite containing $\mathrm{Cu}$ leads to increased surface hardness $(F)$. In the case of polymer-silicate composites were further modified by polyvinylpyrrolidone has been a slight decrease in the elasticity $(S)$, apparently due to the formation of a denser structure under the influence of filler. It should be noticed that all PVC materials are not depending on the content and composition of the polymer-silicate composite significantly increase the Vicat softening point, which increases with the content of polymer-silicate composite and reaches the highest values for fillers that been modified polyvinyl alcohol.

At the same time, the PSF modified with polyvinylpyrrolidone significantly affects the 


\section{Modified polyvinyl chloride composites with metal-containing polymer-silicate fillers}

physical-mechanical and thermophysical properties of PVC composites. This can be caused by the completion of the structure formation process, denser packaging of macromolecules and filling of microcavities under the influence of PVP.

It was found that regardless of the content of PSF in PVC composite, the optimal content of the polymer modifier - polyvinylpyrrolidone in the composition of PSF is $2-5 \%$ wt. (Fig. 2).

A further increase in the content of PVP in PSF leads to a decrease in the surface hardness of PVC composites, which is obviously a consequence of changes in the surface characteristics of the filler under the action of the modifier, in particular, hydrophilization of the surface and formation of less dense interfacial layers.

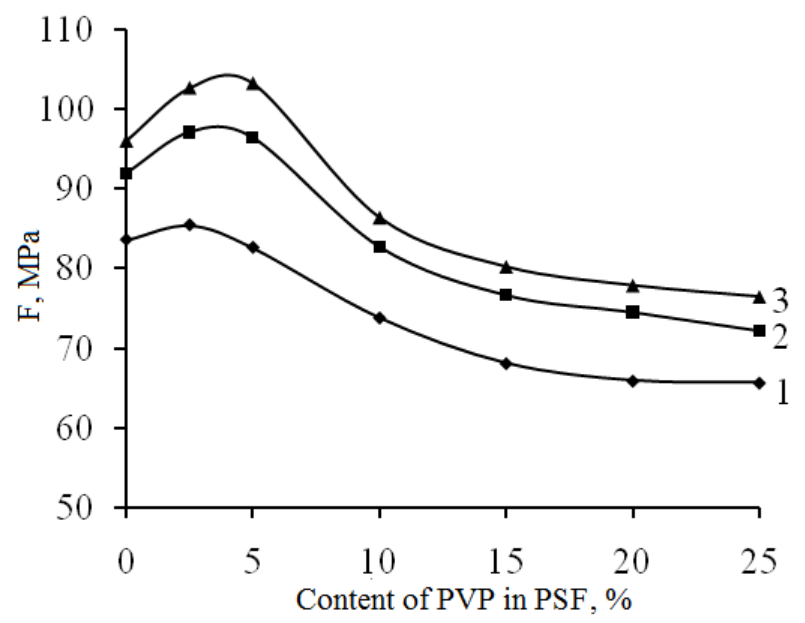

Fig. 2. The effect of PVP content in the modified $C u$-containing silicate filler on the value of the surface hardness of the PVC material (PVC: DOP = 100: 30). PSC content, \%: 1-1, 2-5, 3-10

Established that unmodified $\mathrm{Ba}-\mathrm{Zn}$-containing polymer-silicate composite leads to a significant reduction of elasticity (Table 2).

Table 2

Influence of Ba-Zn containing polymer-silicate composite on physico- mechanical and thermal properties of modified PVC plastic

(PVC: PS: DOP = 100: 2.8: 30 parts by weight)

\begin{tabular}{|c|c|c|c|c|c|}
\hline \multirow[b]{2}{*}{ No. } & \multicolumn{2}{|c|}{ Modifier of PSF, $\% \mathrm{wt}$} & \multirow[b]{2}{*}{$S, \%$} & \multirow[b]{2}{*}{$\begin{array}{c}F, \\
\mathrm{MPa}\end{array}$} & \multirow[b]{2}{*}{$\begin{array}{c}T_{V}, \\
\mathrm{~K}\end{array}$} \\
\hline & $\begin{array}{l}\text { Without } \\
\text { modifier }\end{array}$ & PVA & & & \\
\hline 1 & - & - & 59.0 & 80.7 & 311 \\
\hline 2 & 2 & - & 17.9 & 73.8 & 325 \\
\hline 3 & - & 2 & 80.4 & 108.1 & 322 \\
\hline 4 & - & 10 & 61.7 & 93.3 & 333 \\
\hline
\end{tabular}

However, the introduction of $2 \%$ polymersilicate composite, which was further modified polyvinyl alcohol can increase surface hardness values at $\approx 30 \mathrm{MPa}$ and numbers elasticity $\approx 20 \%$. It should be noted that the content of $10 \%$ $\mathrm{Ba}-\mathrm{Zn}$-containing polymer-silicate composite modified polyvinyl alcohol, there is some reduction in the value of elasticity. The influence of Ba-Zn-containing polymer-silicate composites on Vicat softening point of PVC plastic was found. The highest values have a composition which is a polymer-silicate composite modified by polyvinyl alcohol content of $10 \%$.

It was found the influence of polymer-silicate composite of different nature and composition on thermomechanical properties of PVC materials (Fig. 3).

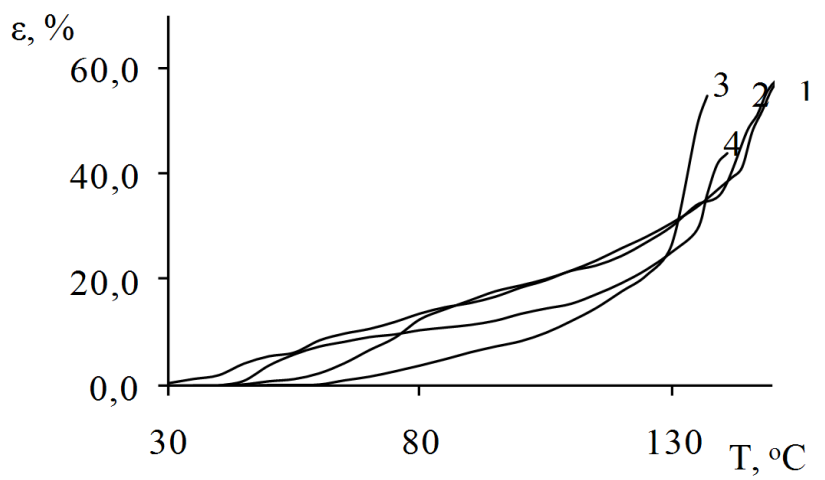

Fig. 3. Effect of polymer-silicate composite on thermomechanical properties of modified PVC plastic by polystyrene ( $P V C: D O P: P S=100: 30: 2,8)$. Filler:

1 - without polymer-silicate composite;

$2-Z n, B a-$ polymer-silicate composite ( $1 \%)$;

3 - Zn, Ba-polymer-silicate composite (10\%);

$4-Z n, B a$-polymer-silicate composite (2\%).

Modifier of polymer-silicate composite:

1, 2 - without modifier; 3, 4-polyvinyl alcohol

Past thermomechanical studies suggest a decrease in strain modified polymer-silicate composite PVC material in the low temperature range. This modified by polyvinylpyrrolidone polymer-silicate composite substantial impact on physic-mechanical and thermal properties of PVC composites. This may be due to the completion of the process of structure formation, dense packing of macromolecules and filling the pores under the influence of macromolecules polyvinyl alcohol in their content of 2-5\% in silicate fillers.

\section{Conclusions}

The investigation, described above have shown that the directed introduction of fine metal- 


\section{A. S. Masyuk, D. S. Katruk, V. Ye. Levytsky}

polymer-silicate fillers and polystyrene modifiers can influence the morphology of PVC materials and thus achieve the desired set of physico-mechanical, thermal and physicochemical properties of composites for a specific practical use can be achieved. It has been established that the optimal content of polymersilicate composite is $2-5 \%$ by weight. When used as a filler the metal-polymer-silicate filler modified by polyvinyl alcohol increases surface hardness values of PVC by $\approx 30 \mathrm{MPa}$, number elasticity by $\approx 20 \%$ and Vicat softening point by $15-25 \mathrm{~K}$.

\section{Reference}

1. Kerber, M. L., Vinogradov, V. M., Golovkin, G. S., Berlina, A. A. (Eds.) (2008). Polimernyye kompozitsionnyye materialy. SP.: Professiya.

2. Rakesh, K. Gupta, Elliot, Kennel, Kwang-Jea, Kim (2009). Polymer Nanocomposites Handbook. Cambridge: CRC Press.

3. Long, A. C. (2007). Composites forming technologies. Cambridge: Woodhead Publishing House, 344.

4. Agassant, J.-F., Avenas, P., Carreau, P. J., Vergnes, B., Vincent, M. (2017). Polymer Processing Principles and Modellin. Munich:Hanser, 320.

5. Fink, F. J. (2010). A concise introduction to additives for thermoplastic Polymers. Hoboken, Salem: Wily-Scrivener, 282.

6. Xantos, M. (2010). Functional fillers for plastics, 2nd edition. Weinhem: Wiley-VCH, 531.

7. Levytskyi, V., Masiuk, A., Katruk, D., Kuzioła, R., Bratychak, M. Jr., Chopyk, N., Khromyak, U. (2020). Influence of polymer-silicate nucleator on the structure and properties of polyamide 6. Chemistry \& Chemical technology, 12, 53-57.
8. Levyts'kyi, V., Masyuk, A., Bialopiotrowicz, T., Bilyi, L. and Humenets'kyi, T. (2018). Morphology and properties of thermoplastic composites with modified silicate fillers. Materials Science, 54, 48-54.

9. Stipanelow Vrandecic N., Klaric, I., Roje, U. (2001). Effect of $\mathrm{Ca} / \mathrm{Zn}$ stabiliser on thermal degradation of poly (vinyl chloride) / chlorinated polyethylene blends, Polymer Degradation and Stability, 74, 203-212.

10. Levytskyi, V. Ye., Masyuk, A. S., Suberlyak, O. V. (2017). Preparation and properties of polymer-silicate composites based on hydrophilic polymers. Voprosy Khimii $i$ Khimicheskoi Tekhnologii, 6, 68-74.

11. Масюк, А. С., Левицький, В. Є., Чекайло, М. В. (2015). Вплив полівінілового спирту на закономірності одержання і морфологію Вa-Zn вмісних силікатних матеріалів. Вісник Наи. ун-ту “Львівська політехніка": Хімія, технологія речовин та їх застосування, 812, 131-136.

12. Masyuk, A. S., Levytskyi, V. Y., Chyzhovych, R. A. (2019). Surface characteristics of materials based on sodium liquid glass modified by polyvinyl alcohol and polyvinylpyrrolidone. Хімія, технологія речовин та їх застосування, 2, 1, 127-132.

13. Masyuk, A. S., Levytskyi, V. Ye., Boiko, M. V., Kulish, B. I. (2020). Influence of metal-containing polymersilicate filler on the technological properties of polypropylene. Хімія, технологія речовин та їх застосування, 1, 3, 133-138.

14. Масюк, А. С., Хром'як, У. В., Ващук, К. І., Левицький, В. Є., Бойко, М. В. (2018). Вплив металовмісного полімер-силікатного наповнювача на технологічні властивості полікапроаміду. Хімія, технологія речовин та їх застосування, 1, 1, 133-138.

А. С. Масюк, Д. С. Катрук, В. Є. Левицький

Національний університет "Львівська політехніка", кафедра хімічної технології переробки пластмас

\section{МОДИФІКОВАНІ ПОЛІВІНІЛХЛОРИДНІ КОМПОЗИТИ З МЕТАЛОВМІСНИМИ ПОЛІМЕР-СИЛІКАТНИМИ НАПОВНЮВАЧАМИ}

Досліджено вплив природи металовмісних полімер-силікатних наповнювачів на морфологію, поверхневу твердість, теплостійкість за Віка та пружно-пластичні властивості ПВХ пластикатів. Встановлено вплив полімер-силікатних наповнювачів на фізико-механічні, теплофізичні властивості та умови спрямованого регулювання технологічних та експлуатаційних властивостей модифікованих композитів.

Ключові слова: полівінілхлорид; модифікування; полімер-силікатний наповнювач; композит. 